\title{
Heavy Trucks, Conspicuity Treatment, AND tHe DECLINE OF COLLISION RISK IN DARKNESS
}

\author{
JOHN M. SULLIVAN \\ MichaEL J. FlanNagan
}

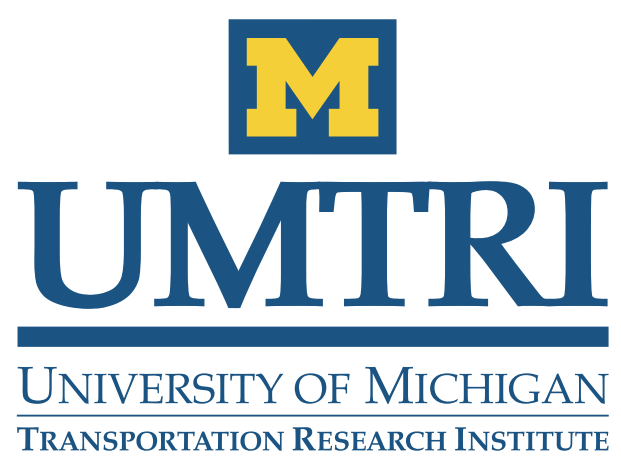




\title{
HEAVY TRUCKS, CONSPICUITY TREATMENT, AND THE DECLINE OF COLLISION RISK IN DARKNESS
}

\author{
John M. Sullivan \\ Michael J. Flannagan
}

The University of Michigan

Transportation Research Institute

Ann Arbor, Michigan 48109-2150

U.S.A.

Report No. UMTRI-2011-18

September 2011 


\begin{tabular}{|c|c|c|c|c|}
\hline \\
\hline $\begin{array}{l}\text { 1. Report No. } \\
\text { UMTRI-2011-18 }\end{array}$ & \multicolumn{2}{|c|}{ cession No. } & \multicolumn{2}{|l|}{ 3. Recipient's Catalog No. } \\
\hline \multirow{2}{*}{\multicolumn{3}{|c|}{$\begin{array}{l}\text { 4. Title and Subtitle } \\
\text { Heavy Trucks, Conspicuity Treatment, and the Decline of } \\
\text { Collision Risk in Darkness }\end{array}$}} & \multicolumn{2}{|l|}{$\begin{array}{l}\text { 5. Report Date } \\
\text { September } 2011\end{array}$} \\
\hline & & & \multicolumn{2}{|c|}{$\begin{array}{l}\text { 6. Performing Organization Code } \\
302753\end{array}$} \\
\hline \multicolumn{3}{|c|}{$\begin{array}{l}\text { 7. Author(s) } \\
\text { John M. Sullivan and Michael J. Flannagan }\end{array}$} & \multicolumn{2}{|c|}{$\begin{array}{l}\text { 8. Performing Organization Report No. } \\
\text { UMTRI-2011-18 }\end{array}$} \\
\hline \multirow{2}{*}{\multicolumn{3}{|c|}{$\begin{array}{l}\text { 9. Performing Organization Name and Address } \\
\text { The University of Michigan } \\
\text { Transportation Research Institute } \\
\text { 2901 Baxter Road } \\
\text { Ann Arbor, MI } 48109-2150 \text { U.S.A }\end{array}$}} & \multicolumn{2}{|l|}{ 10. Work Unit no. (TRAIS) } \\
\hline & & & \multicolumn{2}{|l|}{ 11. Contracts or Grant No. } \\
\hline \multirow{2}{*}{\multicolumn{3}{|c|}{$\begin{array}{l}\text { 12. Sponsoring Agency Name and Address } \\
\text { The University of Michigan } \\
\text { Industry Affiliation Program for } \\
\text { Human Factors in Transportation Safety }\end{array}$}} & \multicolumn{2}{|c|}{ 13. Type of Report and Period Covered } \\
\hline & & & \multicolumn{2}{|l|}{ 14. Sponsoring Agency Cods } \\
\hline \multicolumn{5}{|c|}{$\begin{array}{l}\text { 15. Supplementary Notes } \\
\text { The Affiliation Program currently includes Alps Automotive/Alpine Electronics, } \\
\text { Autoliv, BMW, Chrysler, Ford, General Motors, Gentex, Grote Industries, Honda, } \\
\text { Ichikoh Industries, Koito Manufacturing, Magna Donnelly, Nissan, North American } \\
\text { Lighting, OSRAM Sylvania, Philips Lighting, Renault, SABIC Innovative Plastics, } \\
\text { Stanley Electric, Toyota Technical Center USA, Truck-Lite, Valeo, Valeo Sylvania, and } \\
\text { 3M Visibility and Insulation Solutions. Information about the Affiliation Program is } \\
\text { available at: http://www.umich.edu/ industry/ }\end{array}$} \\
\hline \multicolumn{5}{|c|}{$\begin{array}{l}\text { In December 1992, Federal Motor Vehicle Safety Standard (FMVSS) } 108 \text {, was amended to } \\
\text { require conspicuity treatments on all heavy trailers manufactured after December } 1,1993 \text {. The } \\
\text { standard was later modified and extended to tractors and older trailers such that by June } 1,2009 \\
\text { the entire fleet of tractors and semitrailers on United States roadways would reach full } \\
\text { compliance with the regulation. To investigate the effect of the regulation, an analysis was } \\
\text { conducted of the change in the odds that a fatal crash occurred in darkness, comparing scenarios } \\
\text { in which the conspicuity treatment was likely to be influential to those in which the conspicuity } \\
\text { treatment was likely to be irrelevant. From } 1987 \text { to } 2009 \text {, the odds that a fatal collision involving } \\
\text { a heavy truck occurred in darkness declined by } 58 \% \text { among the relevant crash scenarios, while } \\
\text { little evidence of decline was found among the irrelevant scenarios. Disaggregations of crash } \\
\text { scenario types suggest that the largest declines occurred in fatal rear end and angle collisions. A } \\
\text { comparative analysis of light vehicles also found declines, although they were smaller and less } \\
\text { sensitive to crash type. Similar but weaker trends were observed for nonfatal rear end collisions. } \\
\text { The results are consistent with causal mechanisms that suggest that detection failure may be a } \\
\text { significant contributor to the risk of striking a tractor-semitrailer in darkness, and that conspicuity } \\
\text { treatments have significantly reduced this risk. }\end{array}$} \\
\hline \multicolumn{2}{|c|}{$\begin{array}{l}\text { 17. Key Words } \\
\text { Conspicuity marking, FMVSS 108, heavy } \\
\text { vehicles, rear end collisions, tractor-semitrailer }\end{array}$} & \multicolumn{3}{|c|}{$\begin{array}{l}\text { 18. Distribution S } \\
\text { Unlimited }\end{array}$} \\
\hline $\begin{array}{l}\text { 19. Security Classification (of this report) } \\
\text { None }\end{array}$ & \multicolumn{2}{|c|}{$\begin{array}{l}\text { 20. Security Classification (of this page } \\
\text { None }\end{array}$} & $\begin{array}{c}\text { 21. No. of Pages } \\
21\end{array}$ & 22. Price \\
\hline
\end{tabular}




\section{Acknowledgements}

Appreciation is extended to the members of the University of Michigan Industry Affiliation Program for Human Factors in Transportation Safety for support of this research. The current members of the Program are:

Alps Automotive/Alpine Electronics

Autoliv

BMW

Chrysler

Ford

General Motors

Gentex

Grote Industries

Honda

Ichikoh Industries

Koito Manufacturing

Magna Donnelly
Nissan

North American Lighting

OSRAM Sylvania

Philips Lighting

Renault

SABIC Innovative Plastics

Stanley Electric

Toyota Technical Center, USA

Truck-Lite

Valeo

Valeo Sylvania

3M Visibility and Insulation Solutions 


\section{Contents}

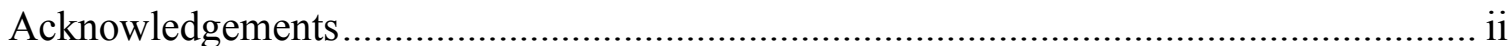

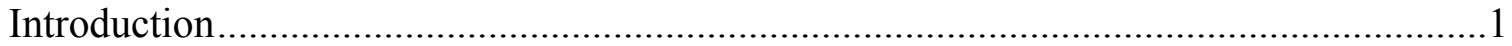

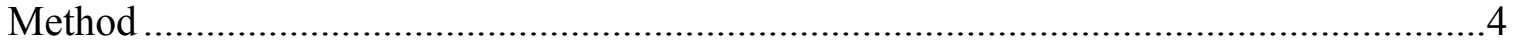

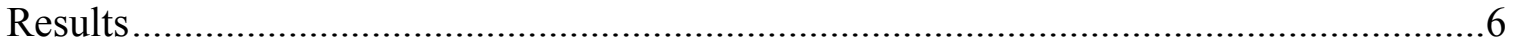

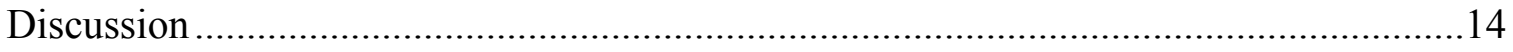

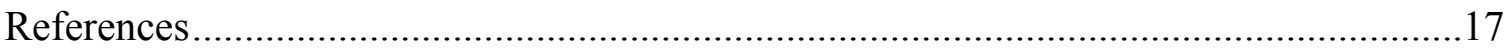




\section{Introduction}

In a 1977 analysis of fatal car-truck underride crashes in Michigan and Texas, Minahan and O'Day (1977) noted that such accidents were most common on straight rural roadways at night. They went on to suggest that, while more effective methods of underride prevention could be useful, making tractors and semi-trailers more conspicuous might help reduce the occurrence of such crashes in the first place. Thus, a clear linkage was drawn between the visibility of heavy trucks and crash risk.

A follow-up study (Green, Kubaki, Olson, \& Sivak, 1979) using the National Transportation Safety Administration (NHTSA) 1977 Fatality Analysis Reporting System (FARS) indicated that disproportionately more fatal crashes involving angle and rear end collisions between cars and tractor-semitrailers occurred at night, suggesting that the addition of lights or retroreflective paint would reduce the frequency of these crashes. In 1980, NHTSA initiated a research program examining the issue of truck conspicuity in detail (Burger, Mulholland, \& Smith, 1985; Burger et al., 1981; Ziedman, Burger, Smith, Mulholland, \& Sharkey, 1981). This led to a proposed revision of Federal Motor Vehicle Safety Standard No. 108 in 1991 to include conspicuity treatments for tractor-semitrailers (combination vehicles) in the safety standard.

NHTSA published their initial rule on December 10, 1992. It required all trailers exceeding $10,000 \mathrm{lbs}(4,536 \mathrm{~kg})$ or 80 inches $(2,032 \mathrm{~mm})$ in width and manufactured on or after December 1, 1993 be equipped with markings on the sides and rear to make them more visible on the roadway. The prescribed conspicuity markings could be made of two materials: reflex reflectors, or retroreflective sheeting material; they were required to be affixed across the full width of the rear trailer between 15 and 60 inches (375 and 1525 $\mathrm{mm}$ ) above the road surface and to outline the upper right and left corners and the sides of the trailer (for details, see Federal Motor Carrier Safety Administration, 2001). The Federal Motor Carrier Safety Regulations (FMCSRs) were later amended on March 31, 1999 to require installation of conspicuity treatment on trailers manufactured prior to December 1, 1993. Older trailers were required to have some form of reflex reflector or retroreflective tape installed by June 1, 2001; and by June 1, 2009 these trailers were 
required to have conspicuity treatments equivalent to those prescribed for newer trailers in the revision of FMVSS No. 108. NHTSA published further conspicuity requirements for tractors on August 8, 1996, requiring truck tractors manufactured after July 1, 1997 to be equipped with retroreflective material similar to that required for trailers. Thus, the phase-in period for conspicuity treatments spans approximately 20 years. These dates are summarized in Figure 1.

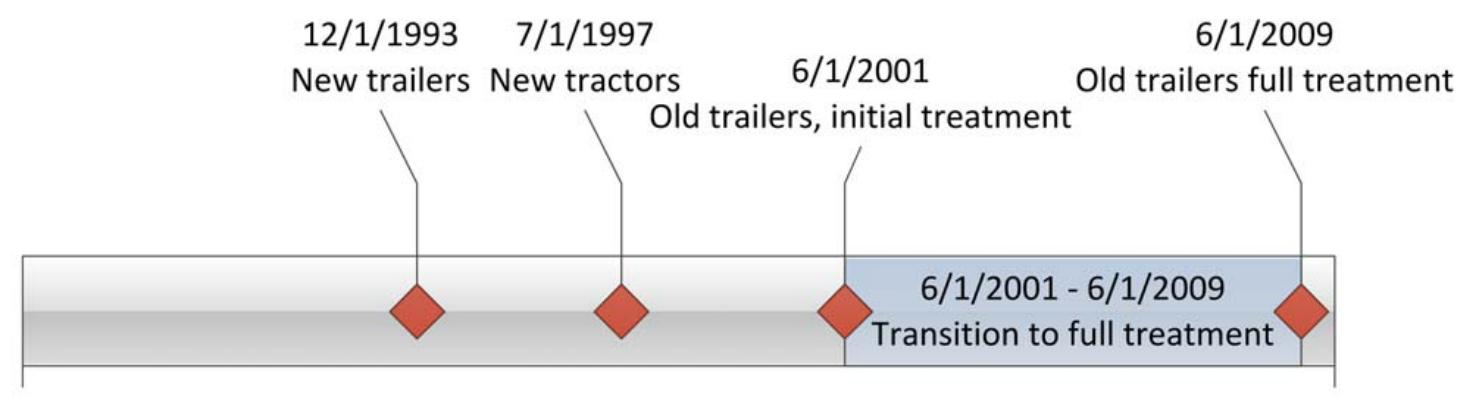

$1 / 1 / 1987$

$12 / 31 / 2009$

Figure 1. Time line describing the phase-in period for tractor-semitrailer conspicuity treatments. The full span of the timeline shows the crash analysis window used in the FARS crash analysis described later in this report (1987-2009).

Initial estimates of the effectiveness of the conspicuity treatment (Burger et al., 1985) suggested reductions in rear and side impact collisions into tractor-semitrailers at night of about 25 and 15 percent, respectively. Some have argued that the evidence that conspicuity is a major factor in these collisions is relatively weak, arguing that such perceptual factors may play a decisive role in only a very small percentage of such crashes (Ayers, Schmidt, Steele, \& Bayan, 1995). Ayers and colleagues further argued that limitations a driver's capability to detect visual expansion may lead to insufficient time to stop when approaching a stopped vehicle at high closure rates, and that conspicuity treatments can do little to improve this situation. More recently, Morgan (2001) measured the effectiveness of conspicuity by examining state crash data from Florida and Pennsylvania that was supplemented with detailed information about the presence and condition of conspicuity treatments on trucks involved in police-reported 
crashes from 1997 through 1999. Morgan found that the effectiveness of the treatment was greatest in reducing the most severe crashes: fatal rear end and angle crashes into tractor-semitrailers at night decreased by $68 \%$, whereas similar crashes involving injury decreased by $44 \%$. Consistent with Burger et al. (1985), Morgan found the greatest reductions among rear end collisions and more modest reductions for angle collisions.

An effort to examine the effectiveness of conspicuity treatments using daylight saving time (DST) analysis was reported in Sullivan (2005). In that analysis, the transition period over which use of conspicuity treatments was phased in was divided in half: 1987 to 1995 , a period in which relatively fewer tractor-semitrailers were likely to be equipped with the conspicuity treatments; and 1996 to 2003, a period in which more tractor-semitrailers were likely to be so equipped. Although the expected decline in the odds that a fatal rear end collision (involving a struck tractor-semitrailer) occurred in darkness was observed between the earlier and the later periods, a similar decline was observed for struck light vehicles. Because light vehicles are not subject to the conspicuity regulation, it was unclear whether conspicuity treatments were fully responsible for the declines observed among the tractor-semitrailers.

As shown by the timeline in Figure 1, the phase-in of conspicuity treatments for the fleet of tractor-semitrailers in the United States was completed in 2009. At present, a complete set of crash data is now available that spans this transition period, making it feasible to examine the transition period using both NHTSA's FARS dataset and the General Estimates System (GES) sample of fatal and nonfatal crashes. The following crash analysis examines how the odds that a rear end or angle crash occurred in darkness has changed over a 23-year transition period that includes the phase-in period, comparing these odds to the odds of crash types for which the conspicuity treatment is irrelevant. 


\section{Method}

Three analyses of fatal crashes were conducted using FARS data from 1987 to 2009. The first analysis selected all fatal crashes involving no more than two vehicles in which at least one of the involved vehicles was a tractor-semitrailer. Crashes were categorized into conspicuity relevant crashes and conspicuity nonrelevant crashes. The conspicuity relevant crashes included rear end and angle collisions in which the tractorsemitrailer was struck by another vehicle. The conspicuity nonrelevant crashes included single vehicle collisions, front end collisions, and rear end and angle collisions in which the tractor-semitrailer was the striking vehicle. These latter two scenarios excluded cases in which the struck vehicle was another tractor-semitrailer (making the crash conspicuity relevant). Crashes were binned into two categories of light level: Light, which included all crashes occurring in daylight, and Dark, which included all crashes occurring in darkness or darkness with artificial fixed lighting. Crashes that occurred during dawn and dusk were excluded from the analysis.

A logistic regression modeled the odds that a fatal crash occurred in darkness as a function of year of the crash and category of crash (relevant/nonrelevant). The expected result was an interaction effect such that a strong decline in the odds of a crash in darkness would be observed over years for relevant crashes, while little change would be observed among the nonrelevant crashes. This analysis was followed by a second regression analysis that disaggregated the relevant and nonrelvant crash types to distinguish differences, for example, between angle collisions and rear end collisions.

To allow a comparison with the previous DST analysis (Sullivan, 2005), a parallel analysis of fatal crashes involving light vehicles was also performed using the same crash types as those used in the second (disaggregated) regression analysis of tractorsemitrailer crashes. Light vehicles included passenger cars, mini-vans, sport utility vehicles, and light trucks. As in the analysis of tractor-semitrailers, striking crashes in which the light vehicle struck a tractor-semitrailer were removed from the analysis. Thus, unlike the tractor-semitrailer analysis, all light vehicle crashes in the sample should be nonrelevant with respect to conspicuity regulations. Any trends observed among the 
light vehicle crashes are thus not likely to be associated with the conspicuity regulations, and may represent other factors influencing the dark/light odds.

Finally, an analysis of injury-only crashes was conducted using GES data from 1988 to 2009. While FARS is a complete census of all fatal crashes in the United States, GES is a sample of crashes weighted to extrapolate to national crash levels. Consequently, the GES extrapolations contain a degree of sampling error. Like the FARS analysis, all tractor-semitrailer crashes were selected involving no more than two vehicles, crash scenarios were categorized as relevant or nonrelevant, and light level was binned into light and dark. The sample of crashes was restricted to injury crashes. Injury crashes included the imputed maximum severities (variable MAXSEV_I) of: possible injury, nonincapacitating injury, incapacitating injury, and injured-but-unknown severity. 


\section{Results}

Fatal Crashes. An overview of the distribution of crash types involving tractorsemitrailers by ambient light conditions is shown in Table 1. In general, fatal crashes involving tractor-semitrailers are most common in daylight and likely reflect higher traffic levels during daylight hours. A significant exception to this is rear end collisions in which a tractor-semitrailer is the struck vehicle. The odds that this type of crash occurs in darkness are about 1.5. It is the only fatal crash type that is more common in darkness than in daylight, despite the likely opposing influence of exposure. These data, partitioned by year, are used as the basis of the following logistic regressions.

Table 1

Cumulative fatal crashes involving tractor-semitrailers between 1987 and 2009, stratified by ambient light and crash type.

\begin{tabular}{|c|c|c|c|c|c|}
\hline & Crash Type & Dark & Light & Total & Odds \\
\hline \multirow{4}{*}{ Nonrelevant } & Angle - Striking & 3,042 & 8,671 & 11,713 & 0.351 \\
\hline & Front End & 4,751 & 7,726 & 12,477 & 0.615 \\
\hline & Rear End - Striking & 1,120 & 1,362 & 2,482 & 0.822 \\
\hline & Single Vehicle & 2,280 & 2,868 & 5,148 & 0.795 \\
\hline \multirow{2}{*}{ Relevant } & Rear End - Struck & 3,807 & 2,547 & 6,354 & 1.495 \\
\hline & Angle - Struck & 3,901 & 4,568 & 8,469 & 0.845 \\
\hline \multicolumn{2}{|r|}{ Totals } & 18,901 & 27,742 & 46,643 & 0.681 \\
\hline
\end{tabular}

A logistic regression modeling the odds that a fatal crash occurs in darkness found main effects of crash type (relevant/nonrelevant; Wald $\chi_{(d f=1)}^{2}=90.3, p<.001$ ) and year (Wald $\left.\chi_{(\mathrm{df}=1)}^{2}=30.7, p<.001\right)$. As suggested in prior work, the mean odds of rear end or angle collision (relevant crash) occurring in darkness (at year $=1997$ ) was about twice the odds of a nonrelevant crash. An interaction effect was also observed such that relevant crashes declined by about 3\% per year compared to a base decline of about $1 \%$ per year. These effects are shown in Figure 2. Based on the model, there has been about a $58 \%$ reduction in relevant crashes since the changes in the safety standard were adopted. The resulting model and parameter estimates are shown in Table 2. 


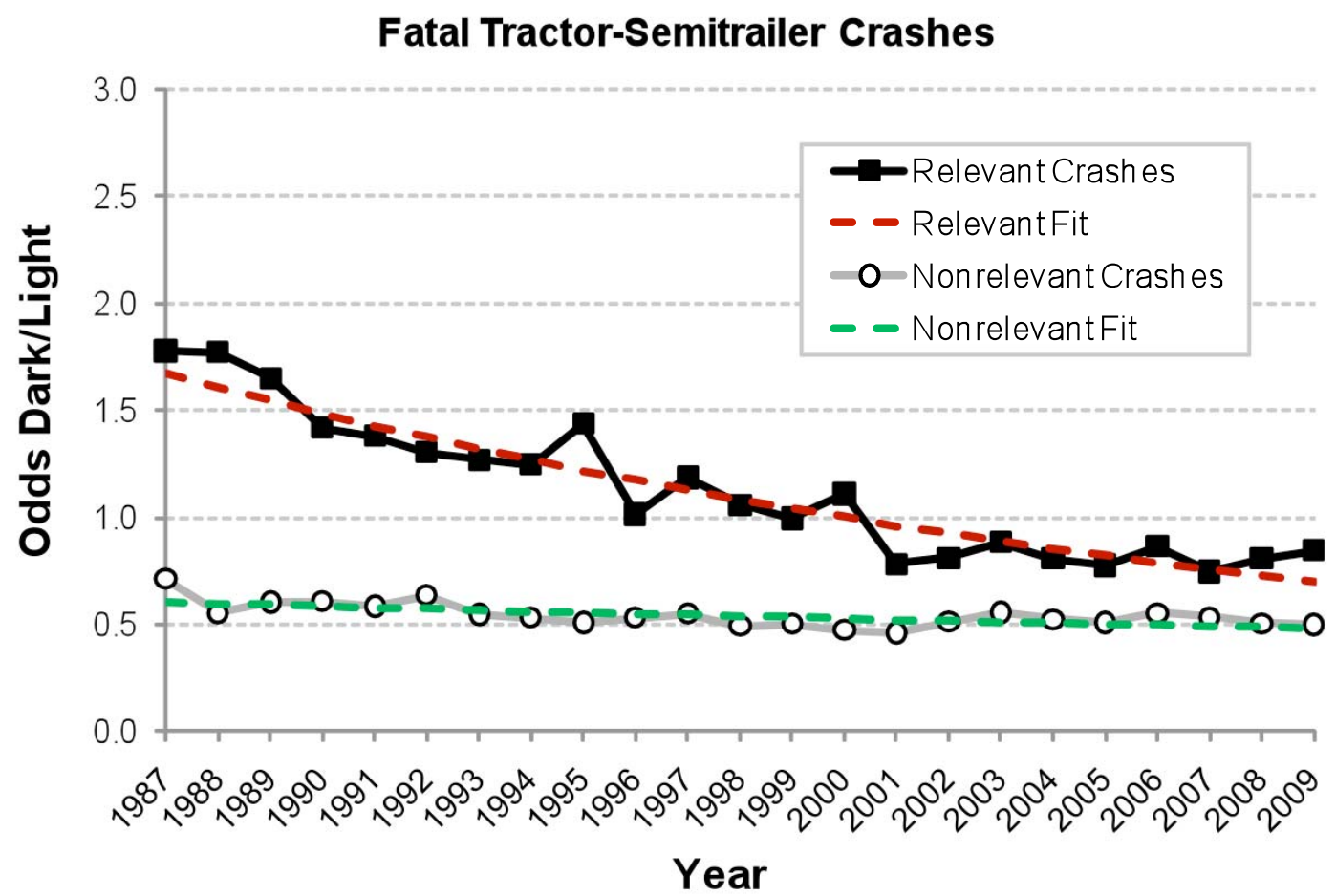

Figure 2. Observed change in odds of a fatal crash in darkness for relevant and nonrelevant crash scenarios.

Table 2

Logistic regression model fit of year and crash type (relevant/nonrelevant) to fatal crashes from FARS 1987 to 2009.

\begin{tabular}{llllccl}
\hline \multicolumn{1}{c}{ Parameter } & df & $\boldsymbol{\beta}$ & $\begin{array}{c}\text { Standard } \\
\text { Error }\end{array}$ & $\begin{array}{c}\text { Wald } \\
\mathbf{X}^{\mathbf{2}}\end{array}$ & $\boldsymbol{p}$ & $\mathbf{e}^{\boldsymbol{\beta}}$ \\
\hline Intercept & 1 & 19.74 & 3.67 & 28.92 & $<.0001$ & $3.73 \mathrm{E}+08$ \\
Type (Relevant) & 1 & 59.41 & 6.25 & 90.35 & $<.0001$ & $6.36 \mathrm{E}+25$ \\
Year & 1 & -0.0102 & 0.002 & 30.74 & $<.0001$ & 0.99 \\
Year x Type (Relevant) & 1 & -0.0294 & 0.003 & 88.22 & $<.0001$ & 0.971 \\
\hline
\end{tabular}

The same data were disaggregated into subtypes of relevant and nonrelevant crashes and reanalyzed to examine differences in the effectiveness of the conspicuity treatments for rear end and angle collisions. To simplify presentation, relevant crashes are shown in Figure 3 and nonrelevant crashes are shown in Figure 4. 
Fatal Tractor-Semitrailer Crashes

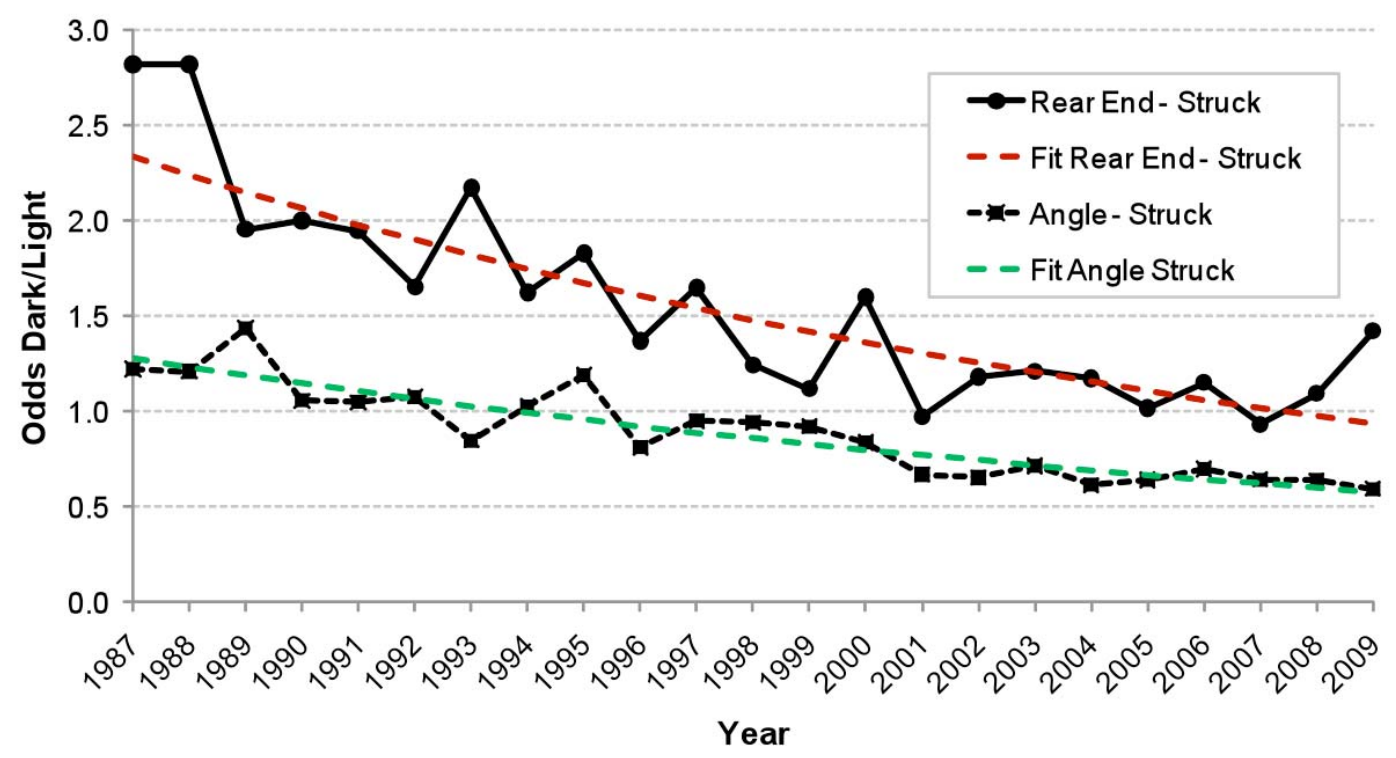

Figure 3. Observed changes in the odds that a relevant fatal collision occurred in darkness over the analysis years. Dashed lines show the model fit to the changes in odds over time.

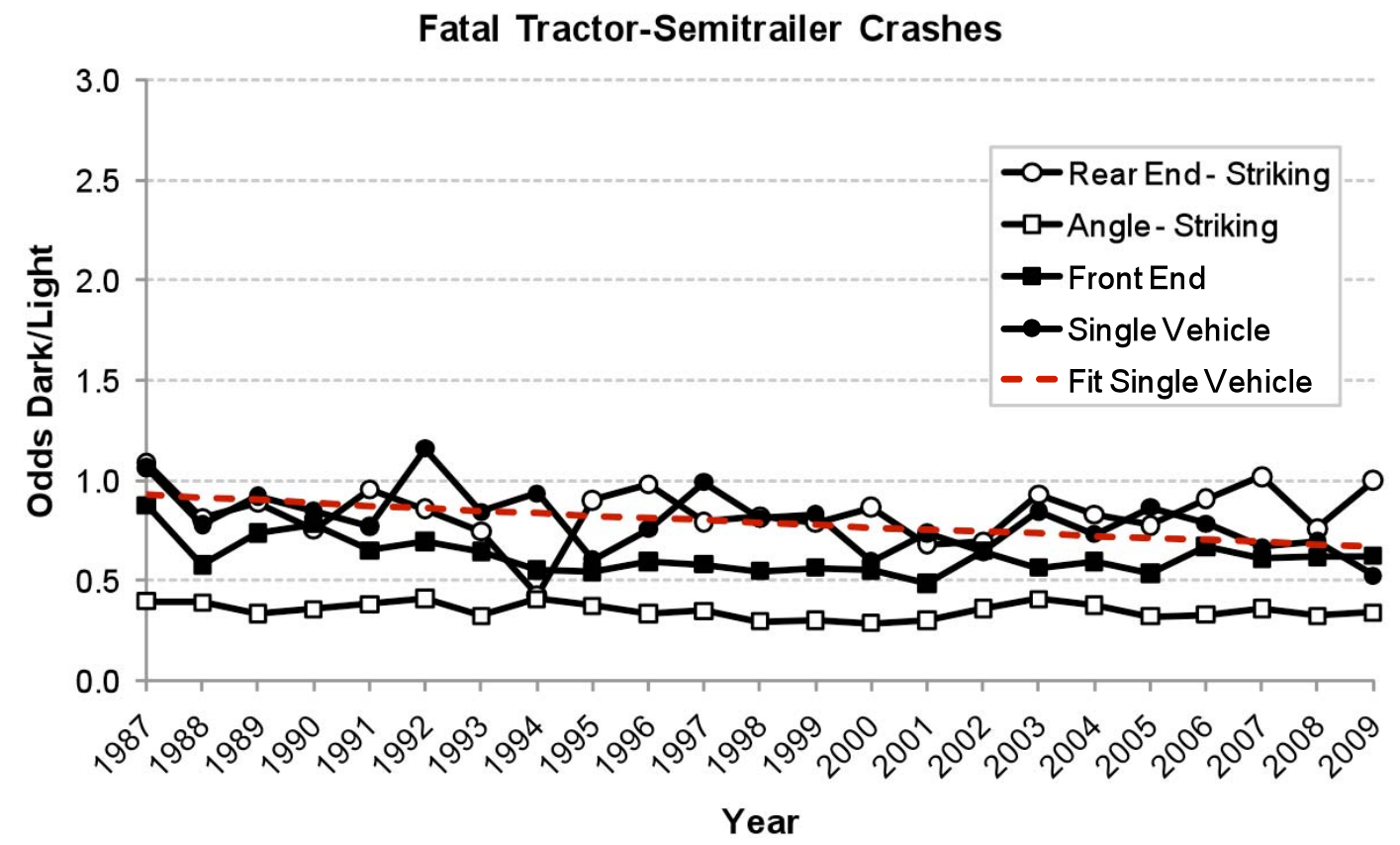

Figure 4. Observed changes in odds that a nonrelevant fatal collision occurred in darkness over the analysis years. Dashed line depicts the model fit to odds of single vehicle crashes in darkness over time. 
The logistic regression indicated main effects of crash type (single vehicle, angle striking, rear end striking, and front end - the nonrelevant crashes; and angle struck and rear end struck - the relevant crashes; Wald $\chi_{(d f=5)}^{2}=94.2, p<.0001$ ), and year (Wald $\left.\chi_{(d f=1)}^{2}=11.9, p<0.0006\right)$. An interaction was also observed between crash type and year (Wald $\left.\chi_{(d f=5)}^{2}=91.9, p<0.0001\right)$, suggesting differences in the change over years in odds that crashes of the various types occurred in darkness. This difference can be seen in the different rates of decline shown in Figure 3 and Figure 4. The decline is about $60 \%$ for rear struck vehicles, and 55\% for angle collisions. The resulting model and parameter estimates are shown in Table 3.

Table 3

Logistic regression model fit of odds that a fatal crash involving a tractor-semitrailer occurred in darkness for year and crash type (FARS 1987 to 2009).

\begin{tabular}{lcrrrrl}
\hline \multicolumn{1}{c}{ Parameter } & df & $\boldsymbol{\beta}$ & $\begin{array}{c}\text { Standard } \\
\text { Error }\end{array}$ & $\begin{array}{c}\text { Wald } \\
\mathbf{X}^{\mathbf{2}}\end{array}$ & $\boldsymbol{p}$ & $\mathbf{e}^{\boldsymbol{\beta}}$ \\
\hline Intercept & 1 & 29.057 & 8.482 & 11.73 & $<0.01^{* *}$ & $4.16 \mathrm{E}+12$ \\
Crash Type: (Single Vehicle) & & & & & & \\
$\quad$ Angle-Striking & 1 & -18.455 & 10.707 & 2.97 & 0.0848 & 0.000 \\
$\quad$ Angle-Struck & 1 & 42.584 & 10.840 & 15.43 & $<0.01^{* *}$ & $3.12 \mathrm{E} 18$ \\
$\quad$ Front End & 1 & -7.037 & 10.354 & 0.46 & 0.50 & 0.001 \\
$\quad$ Rear End Striking & 1 & -30.409 & 15.100 & 4.06 & $0.04^{*}$ & 0.000 \\
$\quad$ Rear End Struck & 1 & 54.112 & 11.528 & 22.03 & $<0.01^{* *}$ & $3.16 \mathrm{E}+23$ \\
Year & 1 & -0.015 & 0.004 & 11.92 & $<0.01^{* *}$ & 0.985 \\
Year x Crash Type & & & & & & \\
$\quad$ Angle-Striking & 1 & 0.009 & 0.005 & 2.71 & 0.10 & 1.009 \\
$\quad$ Angle-Struck & 1 & -0.021 & 0.005 & 15.37 & $<0.01^{* *}$ & 0.979 \\
$\quad$ Front-End & 1 & 0.003 & 0.005 & 0.42 & 0.51 & 1.003 \\
$\quad$ Rear End Striking & 1 & 0.015 & 0.008 & 4.06 & $0.04^{*}$ & 1.015 \\
$\quad$ Rear End Struck & 1 & -0.027 & 0.006 & 21.52 & $<0.01^{* *}$ & 0.974 \\
\hline
\end{tabular}

** indicates $p<.01 ; *$ indicates $p<.05$

A comparable logistic regression analysis of the odds that a fatal crash occurred in darkness for light vehicles was also performed using the same crash types used in the preceding analysis. Main effects of crash type (single vehicle, angle striking, rear end striking, front end, angle struck, and rear end struck; Wald $\left.\chi_{(d f=5)}^{2}=19.8, p<.01\right)$, and year (Wald $\left.\chi_{(d f=1)}^{2}=327.4, p<.01\right)$ were observed. An interaction was also observed between crash type and year (Wald $\chi_{(d f=5)}^{2}=15.3, p<.01$ ), indicating that the odds of a crash in darkness have changed differently for different crash types. These changes are shown in Figure 5 and Figure 6. The resulting model and parameter estimates are shown in Table 4. 


\section{Fatal Light Vehicle Crashes}

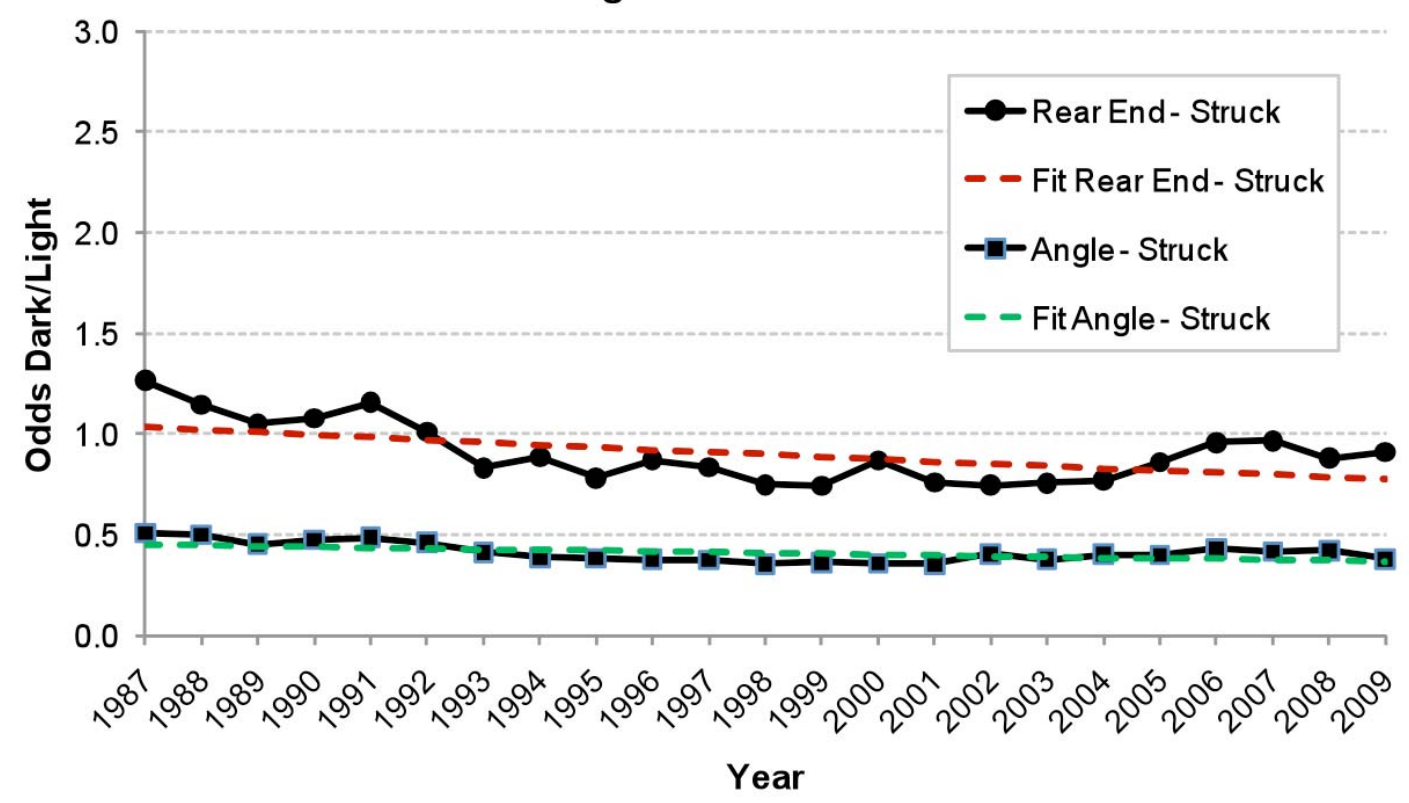

Figure 5. Observed changes in the odds for light vehicles that a fatal rear end or angle crash occurred in darkness over the analysis years. Dashed lines show the model fit to the changes in odds over time.

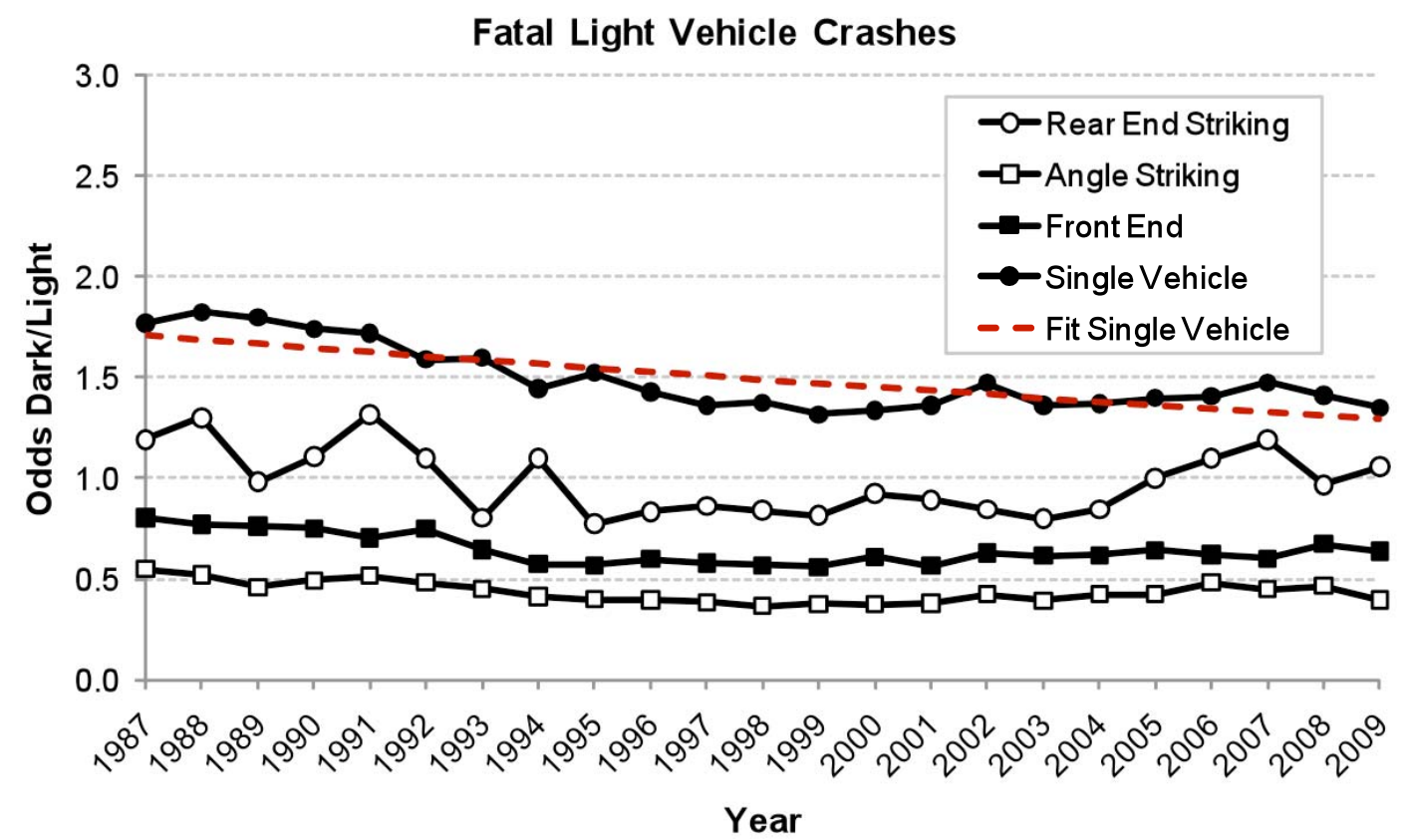

Figure 6. Observed changes in odds for light vehicles that a fatal collision occurred in darkness over the analysis years. Dashed line depicts the model fit to the odds of a single vehicle crash in darkness over time. 
Table 4

Logistic regression model fit of odds that a fatal crash involving a light vehicle occurred in darkness for year and crash type (FARS 1987 to 2009).

\begin{tabular}{lcccccc}
\hline \multicolumn{1}{c}{ Parameter } & df & $\boldsymbol{\beta}$ & $\begin{array}{c}\text { Standard } \\
\text { Error }\end{array}$ & $\begin{array}{c}\text { Wald } \\
\mathbf{X}^{\mathbf{2}}\end{array}$ & $\boldsymbol{p}$ & $\mathbf{e}^{\boldsymbol{\beta}}$ \\
\hline Intercept & 1 & 25.65 & 1.396 & 337.83 & $<0.01^{* *}$ & $1.38 \mathrm{E}+11$ \\
Crash Type: (Single Vehicle) & & & & & & \\
$\quad$ Angle-Striking & 1 & -9.07 & 2.500 & 12.19 & $<0.01^{* *}$ & $1.15 \mathrm{E}-04$ \\
$\quad$ Angle-Struck & 1 & -7.67 & 2.424 & 10.03 & $<0.01^{* *}$ & $4.65 \mathrm{E}-04$ \\
$\quad$ Front End & 1 & -3.10 & 2.124 & 2.13 & 0.14 & 0.045 \\
$\quad$ Rear End Striking & 1 & -11.41 & 5.635 & 4.10 & $0.04^{*}$ & $1.11 \mathrm{E}-05$ \\
$\quad$ Rear End Struck & 1 & 0.17 & 4.989 & 0.00 & 0.97 & $1.19 \mathrm{E}-01$ \\
Year & 1 & -0.01 & 0.0007 & 327.42 & $<0.01^{* *}$ & 0.987 \\
Year x Crash Type & & & & & & \\
$\quad$ Angle-Striking & 1 & 0.004 & 0.0013 & 9.08 & $<0.01^{* *}$ & 1.004 \\
$\quad$ Angle-Struck & 1 & 0.003 & 0.0012 & 6.93 & $<0.01^{* *}$ & 1.003 \\
$\quad$ Front-End & 1 & 0.001 & 0.0011 & 1.12 & 0.29 & 1.001 \\
$\quad$ Rear End Striking & 1 & 0.006 & 0.0028 & 3.80 & 0.051 & 1.006 \\
$\quad$ Rear End Struck & 1 & -0.000 & 0.0025 & 0.02 & 0.89 & 1.000 \\
\hline
\end{tabular}

** indicates $p<.01 ; *$ indicates $p<.05$ 
Injury Crashes. An injury-only aggregate analysis of GES data found no reliable effect of crash type (relevant/nonrelevant), year, or interaction between crash type and year. However, in a follow-on analysis of the disaggregated crash types, a main effect of crash type was observed (Wald $\left.\chi_{(d f=5)}^{2}=18.1, p=.0028\right)$, along with an interaction between crash type and year (Wald $\left.\chi_{(d f=5)}^{2}=17.9, p=.0031\right)$. Notably, the odds that an injury collision involving a struck tractor-semitrailer in a rear end collision occurred in darkness was observed to decline over years, similar to fatal collisions, although the decline is more modest. This is shown in Figure 7 for angle and rear end struck vehicles (relevant crashes), and in Figure 8 for striking angle and rear end collisions, and front end and single-vehicle collisions (nonrelevant crashes). The resulting model and parameter estimates are shown in Table 5.

Table 5

Logistic regression model fit of odds that an injury crash occurred in darkness for year and crash type (GES 1988 to 2009).

\begin{tabular}{lcccccc}
\hline \multicolumn{1}{c}{ Parameter } & df & $\boldsymbol{\beta}$ & $\begin{array}{c}\text { Standard } \\
\text { Error }\end{array}$ & $\begin{array}{c}\text { Wald } \\
\mathbf{X}^{\mathbf{2}}\end{array}$ & $\boldsymbol{p}$ & $\mathbf{e}^{\boldsymbol{\beta}}$ \\
\hline Intercept & 1 & -3.19 & 27.11 & 0.13 & 0.91 & 0.041 \\
Crash Type: & & & & & & \\
$\quad$ Angle-Striking & 1 & 42.53 & 36.08 & 1.39 & 0.24 & $2.95 \mathrm{E}+18$ \\
$\quad$ Angle-Struck & 1 & -19.90 & 28.38 & 0.49 & 0.48 & $2.27 \mathrm{E}-09$ \\
$\quad$ Front End & 1 & -21.11 & 43.27 & 0.24 & 0.62 & $6.80 \mathrm{E}-10$ \\
Rear End Striking & 1 & -8.88 & 41.77 & 0.05 & 0.83 & 0.0001 \\
$\quad$ Rear End Struck & 1 & 74.41 & 45.24 & 2.71 & 0.10 & $2.08 \mathrm{E}+32$ \\
Year & 1 & 0.001 & 0.014 & 0.01 & 0.92 & 1.00 \\
Year x Crash Type & & & & & & \\
$\quad$ Angle-Striking & 1 & -0.022 & 0.018 & 1.44 & 0.23 & 0.98 \\
Angle-Struck & 1 & -0.009 & 0.014 & 0.47 & 0.49 & 1.01 \\
$\quad$ Front-End & 1 & 0.010 & 0.022 & 0.23 & 0.63 & 1.01 \\
Rear End Striking & 1 & 0.004 & 0.021 & 0.04 & 0.85 & 1.00 \\
$\quad$ Rear End Struck & 1 & -0.037 & 0.023 & 2.69 & 0.10 & 0.96 \\
\hline
\end{tabular}




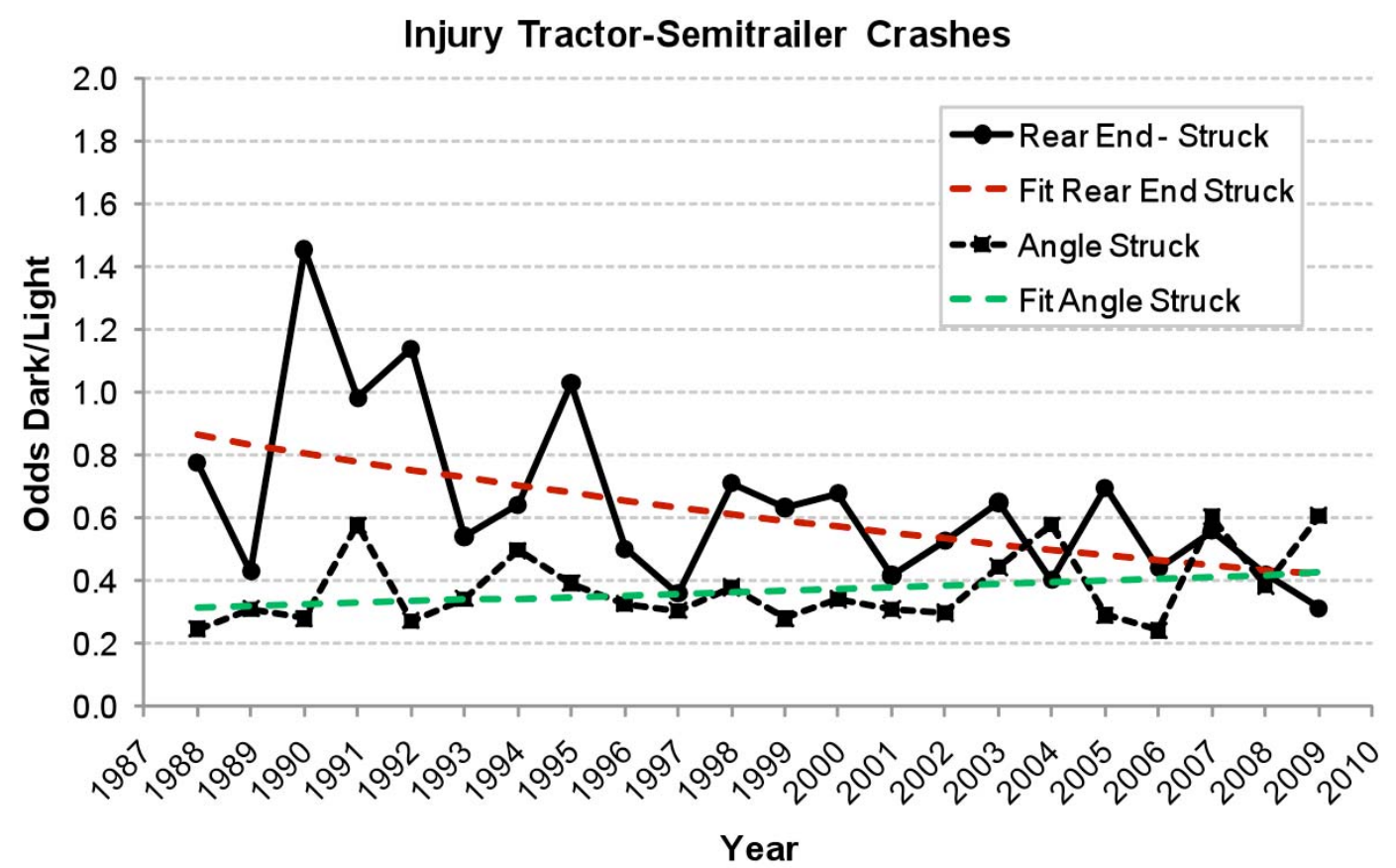

Figure 7. Observed changes in the odds that a relevant injury collision occurred in darkness over the analysis years estimated from GES data 1988-2009. Dashed lines show the model fit to the changes in crash odds over time.

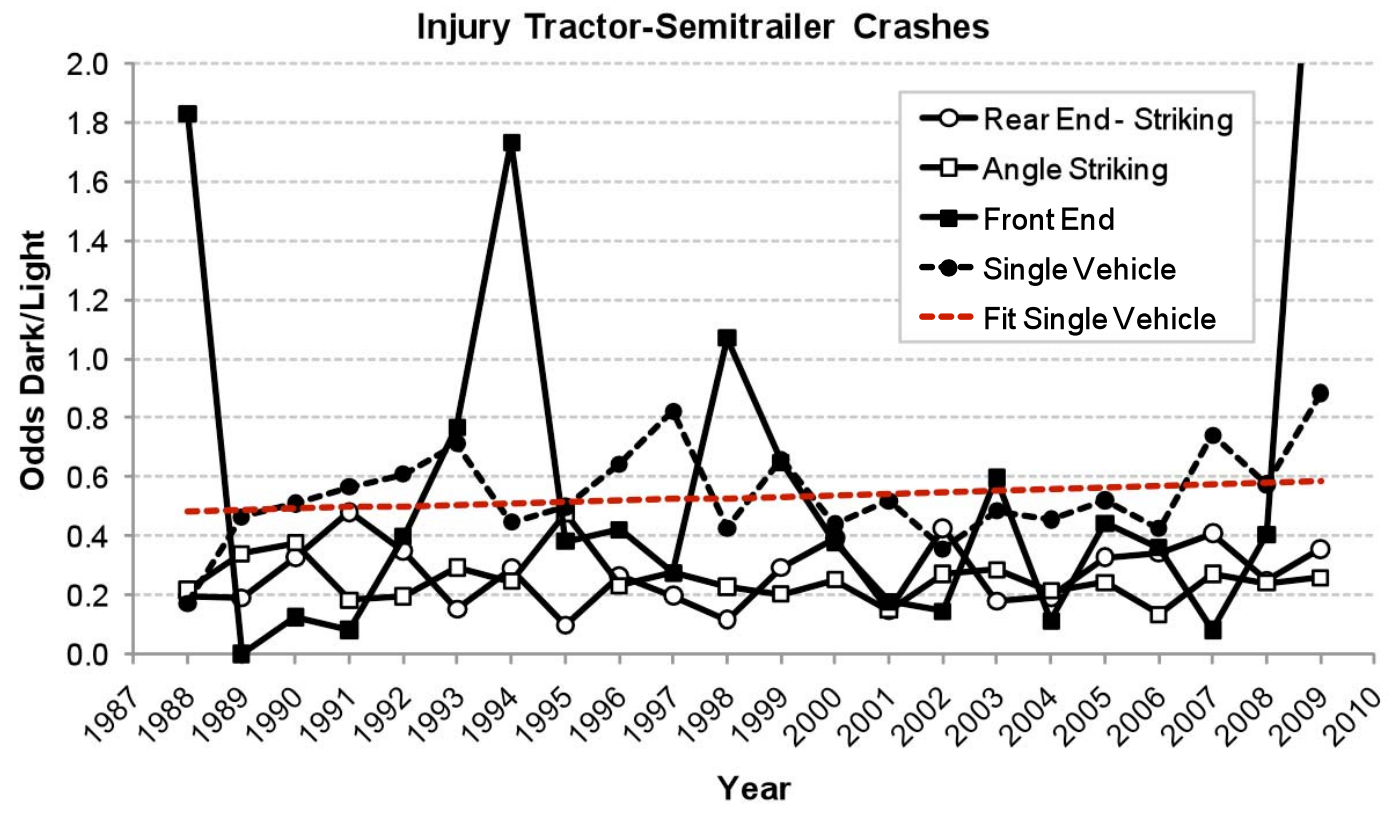

Figure 8. Observed changes in the odds that a nonrelevant injury collision occurred in darkness over the analysis years estimated form GES data 1988-2009. Dashed line indicates model fit for single vehicle crashes. 


\section{Discussion}

The results of the analysis of fatal crashes are consistent with earlier estimates of the effectiveness of conspicuity treatments. Consistent with an earlier analysis (Morgan, 2001) the present analysis of fatal crashes suggests that conspicuity treatments are most effective in reducing rear end collisions and moderately effective in reducing angle collisions in darkness. Observed declines in the present analysis were about $60 \%$ for rear impact collisions and 55\% for angle collisions. Although Morgan's analysis pooled severity levels, her study found similar differences in effectiveness for different crash types. Conspicuity treatments reduced rear impact collisions by about $43 \%$ and angle impact collisions by $17 \%$.

For fatal collisions, Morgan (2001) observed a combined reduction in angle and rear end collisions of about $68 \%$. The corresponding decline in fatal collisions observed in the present analysis for rear end and angle collisions was $58 \%$. These estimates are in rough agreement, and both indicate that the benefits observed from conspicuity markings greatly exceed the projections made during the earliest field tests, which suggested a $25 \%$ reduction in rear end crashes (Burger et al., 1985).

Declines in the odds that a crash occurred in darkness were also observed among light vehicles, suggesting that factors other than conspicuity treatment may contribute to the decline. While consistent with the previous daylight saving time analysis (Sullivan, 2005), the declines are modest compared to those observed for tractor-semitrailers. Using the fitted model, the decline in fatal rear end collision odds in darkness is about $25 \%$. Declines observed among the other light vehicle crash types suggest that nonspecific factors may be broadly influencing a spectrum of crashes. Perhaps campaigns to curb drivers' use of alcohol or driving while fatigued are responsible for some of this decline. In contrast, the tractor-semitrailer pattern of decline is more specific, appearing in rear end collisions and, to a lesser extent, in angle collisions.

It is notable that the odds trends among rear struck light vehicles and tractorsemitrailers, appear to have converged (see Figure 9). Although the relative exposure of heavy trucks and light vehicles to rear end crashes in light and dark conditions may not be equal, this suggests that tractor semi-trailers may now be no less conspicuous than 
light vehicles. It is troubling, however, that the odds that a fatal rear end collision occurs in darkness remain high relative to other crash types. Perhaps other visual factors that cannot be remedied by conspicuity enhancement also present challenges for drivers. For example, darkness may make it difficult to judge approach speed or absolute distance because surrounding visual context is degraded.

The injury-only analysis using GES was consistent with Morgan's previous observations: the effectiveness of conspicuity treatments appears to be weaker for the less severe crashes. A marginal main effect was observed for rear end collisions as well as an interaction with year (see Table 5), similar to the fatal crash analysis. Unlike the fatal crash analysis, the injury-only analysis showed little change in angle collisions involving struck tractor-semitrailers over years.

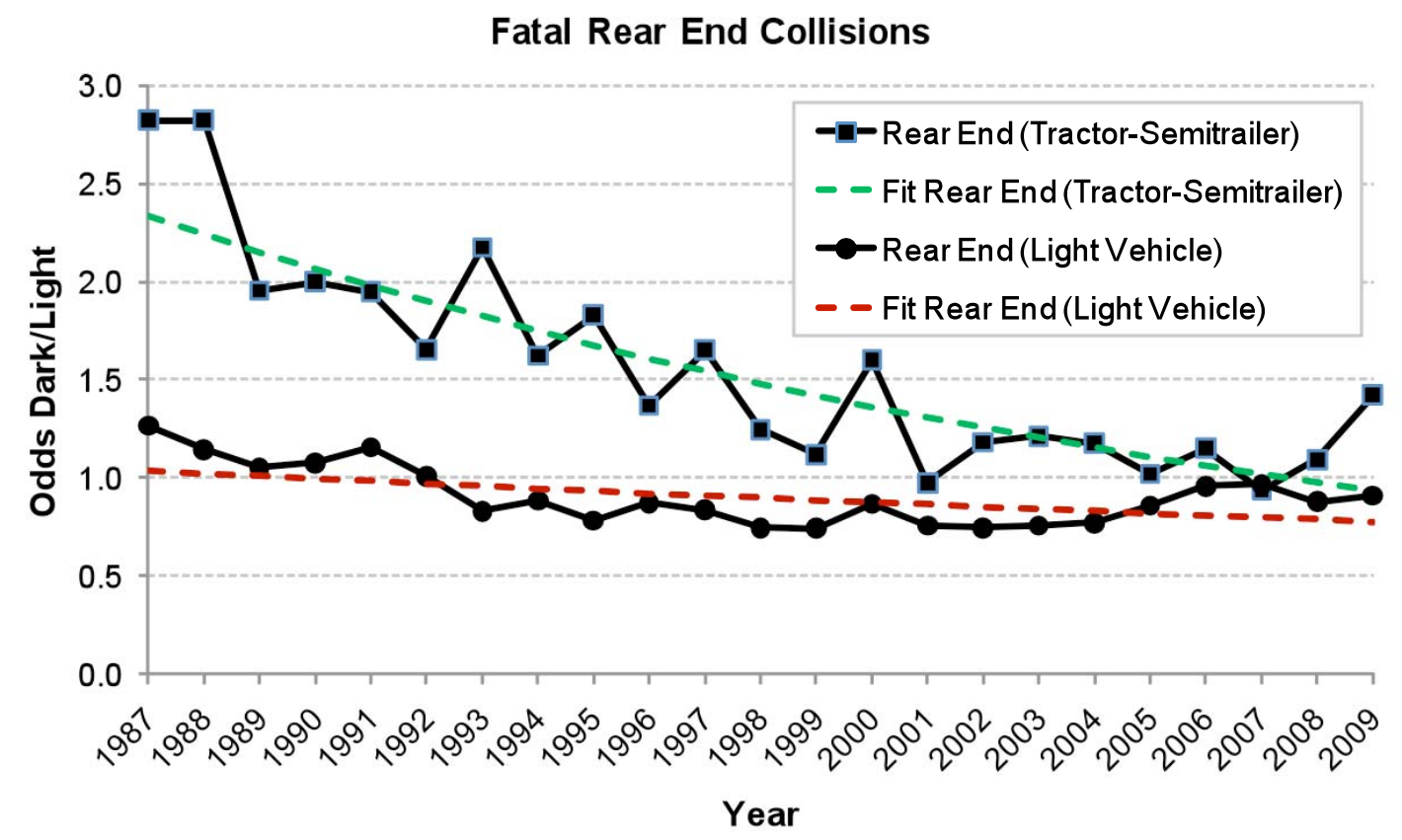

Figure 9. Odds that a fatal crash occurred in darkness by year for tractor-semitrailers and light vehicles.

In summary, this analysis indicates that from 1987 to 2009 there was a strong decline in the odds of nighttime versus daytime rear end and angle crashes of light vehicles into heavy trucks. This change was much larger than any changes observed in control crashes for which truck conspicuity treatments are not relevant (including other types of truck crashes and light vehicle crashes). Because the change took place over the 
years in which truck conspicuity treatments were phased in, the overall pattern of results strongly suggests that the decline in crashes is primarily attributable to those treatments. 


\section{References}

Ayers, T. J., Schmidt, R. A., Steele, B. D., \& Bayan, F. P. (1995). Visibility and judgment in car-truck night accidents. In D. W. Pratt (Ed.), Safety engineering and risk analysis (pp. 43-50). New York: The American Society of Mechanical Engineers.

Burger, W. J., Mulholland, M. U., \& Smith, R. L. (1985). Improved commercial vehicle conspicuity and signaling systems: Task III - field test evaluation of vehicle reflectorization effectiveness. (NHTSA Final Report No. DOT HS 806 923). Santa Monica, CA: Vector Enterprises, Inc.

Burger, W. J., Smith, R. L., Ziedman, K., Mulholland, M. U., Bardales, M. C., \& Sharkey, T. J. (1981). Improved commercial vehicle conspicuity and signalling systems; Task I: Accident analysis and functional requirements. (NHTSA Final Report No. DOT HS 806 100). Santa Monica, CA: Vector Enterprises, Inc.

Federal Motor Carrier Safety Administration. (2001). FMCSA's Conspicuity Requirements for Commercial Motor Vehicles (Report No. DOT-MC-01-129). Washington, D.C.: Federal Motor Carrier Safety Administration.

Green, P., Kubaki, M., Olson, P. L., \& Sivak, M. (1979). Accidents and the nighttime conspicuity of trucks. (Technical Report No. UM-HSRI-79-92). Ann Arbor: University of Michigan Highway Safety Research Institute.

Minahan, D. J., \& O'Day, J. (1977). Car-truck fatal accidents in Michigan and Texas. (Technical Report No. UM-HSRI-77-49). Ann Arbor, MI: Highway Safety Research Institute.

Morgan, C. (2001). The effectiveness of retroreflective tape on heavy trailers. (NHTSA Technical Report No. DOT HS 809 222). Washington, D.C.: National Highway Traffic Safety Administration.

Sullivan, J. M. (2005). Further evidence on the nighttime visibility of trucks. (Technical Report No. No. UMTRI-2005-22). Ann Arbor: The University of Michigan Transportation Research Institute. 
Ziedman, K., Burger, W. J., Smith, R. L., Mulholland, M. U., \& Sharkey, T. J. (1981). Improved commercial vehicle conspicuity and signalling systems; Task II: Analysis, experiments and design recommendations. (NHTSA Final Report No. DOT HS 806 098). Santa Monica, CA: Vector Enterprises, Inc. 